\title{
Mitigation of greenhouse gas emissions from households by urban woodland in Ibagué-Colombia
}

\author{
Luis Miguel Acuña-Simbaqueva \\ Hernán J. Andrade \\ Milena A. Segura \\ Erika Sierra-Ramírez \\ Diana Skarly Canal-Daza \\ Oscar Enrique Greñas-Corrales
}

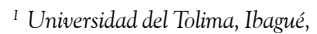
Tolima, Colombia, país.

"I Universidad del Tolima, Ibagué, Tolima, Colombia, país.

(D) III Universidad del Tolima, Ibagué, Tolima, Colombia, país.

IV Universidad del Tolima, Ibagué, Tolima, Colombia, país.

(D) ${ }^{\mathrm{V}}$ Universidad del Tolima, Ibagué, Tolima, Colombia, país.

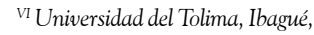
Tolima, Colombia, país.

\begin{abstract}
Trees are essential in the city to capture $\mathrm{CO}^{2}$, and, at the same time, to contribute to the mitigation of climate change. Carbon storage and fixation in aboveground biomass was estimated in the urban woodland of Ibagué with a census from 2013-2016, and a new measurement of $15 \%$ on individuals in the $2019-2020$ period. The number of trees of the main species required to mitigate emissions of greenhouse gases from households was estimated. Urban woodland captures about $3.81 \mathrm{Gg} \mathrm{CO}^{2} /$ year, which represents only $2,3 \%$ of the city emissions. The mitigation of $169.2 \mathrm{Gg} \mathrm{CO}^{2} /$ year of the city households would be achieved by having between 412,000 and 1.2 million trees of the most dominant species. Efforts based on green infrastructure to compensate urban emissions at municipal level must be coordinated with territory policies at large scales.
\end{abstract}

Keywords: Ecosystem services, environmental policy, fixation, storage, urban silviculture.

São Paulo. Vol. 24, 2021

Original Article

DOI: http://dx.doi.org/10.1590/1809-4422asoc20200191vu2021L3AO 


\section{Introduction}

Environmental assets have strategic functions withing cities that look forward to being sustainable. Ecosystem balance between human internvention and care of their resources should be properly planned, because cities and their fast demographic expansion are the main generators of atmosphere pollutants contributing to climate change (GRIMM et al., 2008). Urban worldwide population increased from 751 million in 1950, to 4,2 thousand million in 2018. The regions with the most urbanization are North America, 82\%; Latin America and the Caribbean, 81\%; Europe, 74\%; and Oceania, 68\% (UNITED NATIONS, 2018). These nations have made different proposals to duly plan their development and fulfill their goals concerning climate actions. For example, the goal to contribute with a $20 \%$ reduction of the total greenhouse gas (GHG) emissions in Colombia for 2030 (IDEAM, 2012).

Ibagué, a city in the Colombian Andes area, moved from being a small city with 349,241 inhabitants in 1985, to an intermediate city with 492,524 in 2018 (DANE, 2018). This municipality is ranked eighth in population after Bogotá, Medellín, Cali, Barranquilla, Cartagena, Cúcuta, and Soledad. By extension, it shares the sixth place of the biggest cities in the country with Cúcuta (VILLANUEVA et al., 2016). On this context, some strategies for strengthening environmental management have been established, such as the urban trees census, and the Urban Woodland Silviculture Master Plan (Plan Maestro de Silvicultura del Arbolado Urbano), intending to estimate the role of urban trees in the mitigation of certain negative impacts caused by demographic level and poor management of its natual resources (FINDETER, 2018). Besides, in the Emerging and Sustainable Cities intiative (ESC), developed by the Interamerican Development Bank (IDB), an inhabitatnt of Ibagué has $6.7 \mathrm{~m}^{2}$ of green area, which allows its categorization as a green city (FINDETER, 2018). However, this value does not reach the minimal recommeded by the WHO (0.5-1.0 ha/inhabitant with a distance equal or shorter than $300 \mathrm{~m}$ from their place of living), according to the United Nations Human Settlements (UN-HABITAT, 2018).

Baró et al. (2014), Charoekit and Yiemwattana (2016), Reynolds et al. (2017), Mohamed et al. (2018), and Lindén et al. (2020) have emphasized on the estimation of carbon reservoirs in urban woodlands and their mitigation of GHG emissions. This because perennial woody structure absorbs $\mathrm{CO}_{2}$ and deposits it in biomass and soils as carbon (MCHALE; MCPHERSON; BURKE, 2007; TIMILSINA et al., 2014). $\mathrm{CO}_{2}$ has considerably increased its concentration in atmosphere from the 280 parts per million (ppm) of pre-industrial era to the $411 \mathrm{ppm}$ in 2019, corresponding to a $48 \%$, from which, more than half has been produced in the last 50 years (NOAA, 2019). Urban trees provide different ecosystem services (ES), such as carbon sequestration. A mature tree can sequestrate $150 \mathrm{~kg} \mathrm{CO}_{2} /$ year and, depending on the species and location in the city, can cool the air down between 2 and $8^{\circ} \mathrm{C}$, increase urban biodiversity, regulate water flow and contribute to food and nutritional security (FAO, 2016). It plays an important role in the carbon volunteer global market as land use. The volume of compensation generated by these activities increased around 264\% between 2016 and 2018, growing from $13.9 \mathrm{Mt}$ 
$\mathrm{CO}_{2}$ e to $50.7 \mathrm{MtCO}_{2} \mathrm{e}$, whereas the volume in all other types of compared compensations raised only 21\% (DONOFRIO; MAGUIRRE; MERRY, 2019). These same authors claim that urban woodlands are in a category of predominant project as the world has realized that climate Solutions based on nature are feasible and available.

There have been few studies about urban woodland and ES offer in Colombia, (BORRERO, 2012; REYNOLDS et al., 2017; RODRIGUEZ, 2018; CORTES; MATIAS, 2019; RUANO, 2019). Besides, environmental measurements to mitigate emissions are limited to the use of technology available, energy efficiency and renewable energy actions (BARO et al., 2014). Likewise, those accountable for policy formulation ignore, to a great extent, the potential of green urban spaces to contribute to compliance of environmental goals, considering that environmental offer increases quality of new urbanistic development (ALCALDÍA MUNICIPAL DE IBAGUÉ, 2020).

Carbon biomass in trees has noticeable differences among cities due to the prevalence of weather, history, its urbanization patter and composition of species (LÓPEZ et al., 2018; LINDÉN et al., 2020). Therefore, understanding structure, function and value of urban woodlands contributes to the decisions that improve human health and environment quality, and build joint solutions based on nature creating green jobs and economy (REYNOLDS et al., 2017; LINDÉN et al., 2020). This research assesses the role of urban woodland in aboveground carbon sequestration and mitigation of emissions in the residential area in the city of Ibagué. It also proposes strategies to mitigate such emissions, such as the design of local gevernance tactics based on scientific, ethical, and social criteria oriented to the sustainable development of the cities (IPCC, 2014).

\section{Materials and methods}

\section{Area of study}

The study was carried out in the urban area of the municipality of Ibagué, in the department of Tolima $\left(4^{\circ} 15^{\prime}-4^{\circ} 40^{\prime} \mathrm{N}\right.$ and $\left.74^{\circ} 00^{\prime}-75^{\circ} 30^{\prime} \mathrm{O}\right)$, in the central part of the Colombian Andean region. The urban area of this city is divided into a mountainous and a plain part (CORTOLIMA, 2020). The first one sets in the coffee landscape with a temperature around the $18^{\circ} \mathrm{C}$, while the lower areas are in a landscape of the Magadalena valley, characterized by an average temperature of $24^{\circ} \mathrm{C}$ (IDEAM, 2020). The urban area of Ibagué is classified as pre-montan wet forest (bh-PM) (IDEAM, 2020), it is at an altitude between 615 and $1285 \mathrm{~m}$ with a precipitation level between 1000 and $2000 \mathrm{~mm} /$ year, and especifically between 1400 and $1800 \mathrm{~mm} /$ year in the middle area. The city has an area of $1439 \mathrm{~km}^{2}$, from these 2,4\% belongs to the urban area divided into 13 districts comunas (Figure 1) and 445 neighborhoods (ALCALDÍA MUNICIPAL DE IBAGUÉ, 2020). 
Figure 1 - Political-administrative division of Ibagué, Colombia

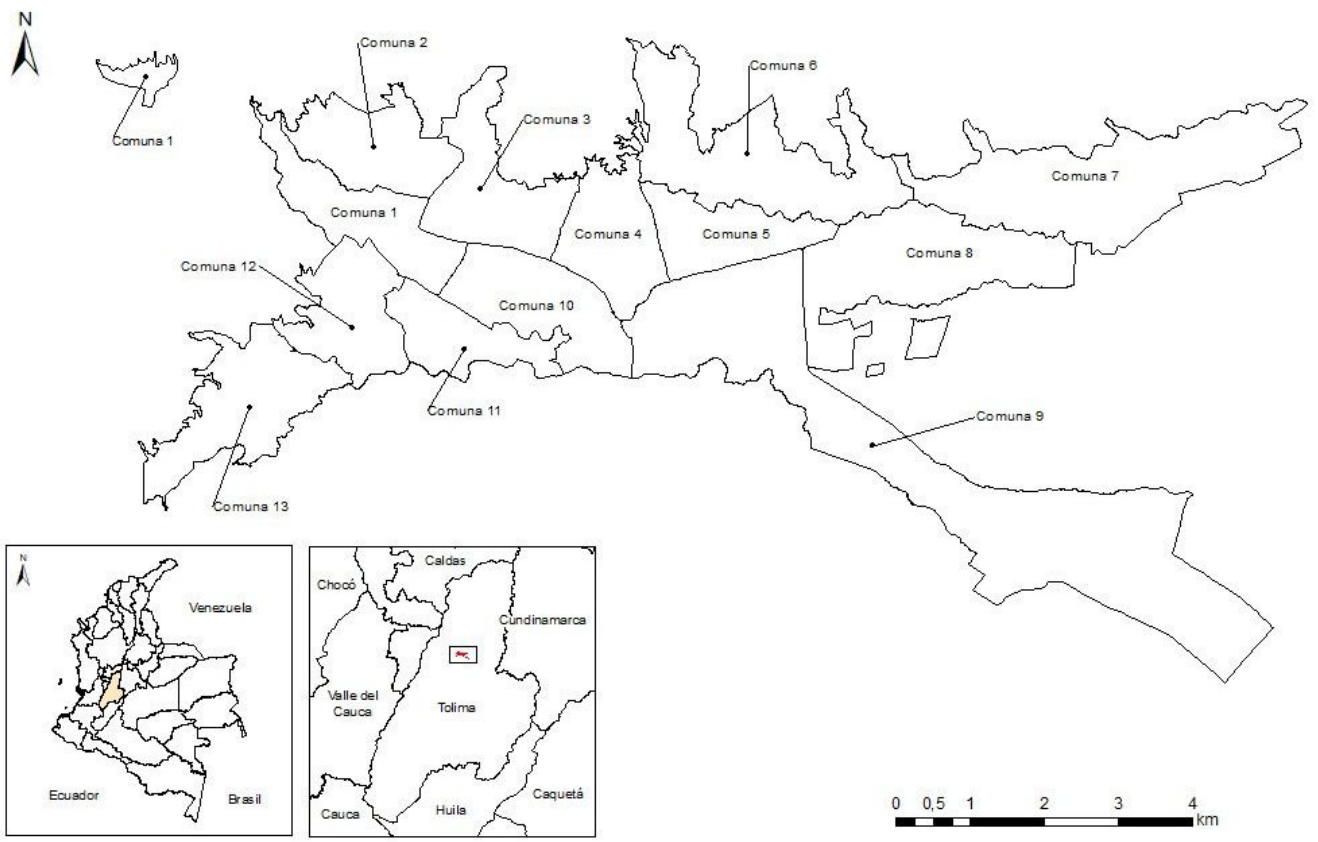

Source: Authors.

The municipality has a projection of 541,101 inhabitants for 2020 (DANE, 2018), where urban population would represent a 94.3-94.5\% of the total (ALCALDÍA MUNICIPAL DE IBAGUÉ, 2016). Ibagué takes second place nationwide as a city with the largest green area per capita $\left(6.7 \mathrm{~m}^{2}\right)$. The first one is Neiva with $7.5 \mathrm{~m}^{2}$; followed by Valledupar, Cartagena, and Bucaramanga with 5.8, 4.6 and $4.5 \mathrm{~m}^{2}$, respectively (FINDETER, 2018). Species of the urban woodland are part of the green infrastructure, and for their maintenance, permanent activities of mowing, pruning and felling (SALBITANO et al., 2017).

\section{Sampling design}

\section{Selection of species to sample}

The study took the census of 101394 urban trees as baseline, measured during three phases, under contracts No. 572 of 2013, No. 672 of 2014, and agreement No. 2095 of 2016 (Municipality) / 056 of 2016 (CORTOLIMA), performed among different institutions (CORTOLIMA et al., 2020). Database was refined considering trees with a trunk diameter at breast height $(\mathrm{dbh}) \geq 10 \mathrm{~cm}$, with a total of 55684 individuals. After that, total and relative basal area per species was estimated to identify the most dominant ones, selecting those which, as a whole, have an $80 \%$ of the basal area.

Dbh was re-measured to approximately 15\% of individuals (7779 trees) of the most dominant species in all the city districts by the end of 2019 and beginning of 2020 , taking 
into consideration the districts and the specific location of each tree (parks, sidewalks or pavement, as well as main and secondary streets).

\section{Aboveground biomass and carbon estimation}

Aboveground biomass of the trees was estimated using the general allometric model by Chave et al. (2005), which considers dbh and basic wood density (Equation 1), those value used was $0.45 \mathrm{~g} / \mathrm{cm}^{3}$ (ALVAREZ et al., 2011). Carbon was estimated multiplying by 0.47 , the default carbon fraction recommended by the IPCC (2007) for tropical areas.

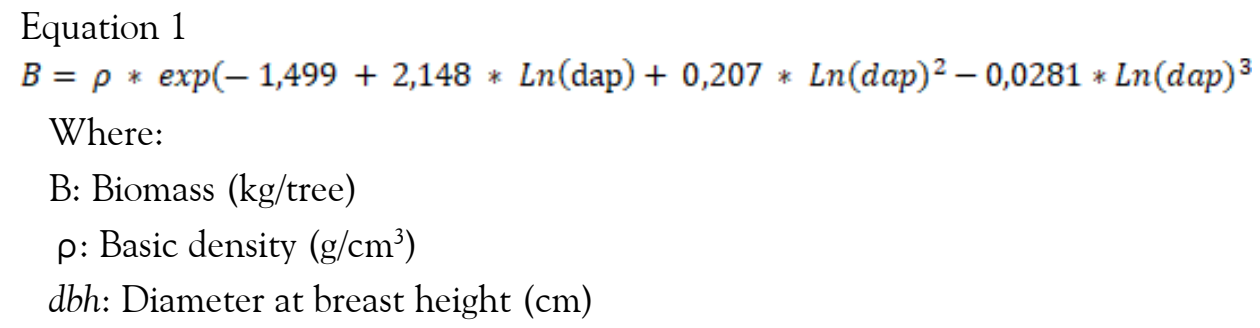

Carbon sequestration was estimated based on the annual periodic increment (API), considering the increase in carbon storage between measurements divided by the time between them (JUAREZ, 2014). Carbon fixation values were changed to $\mathrm{CO}_{2} \mathrm{e}$, and using the stoichiometric factor of 3.67 (IPCC, 2007). Based on carbon storage in the census measurement (2013-2016), in the re-measurement (2019-2020), and the carbon fixation rate of trees re-measured, the fixation rate for the entire urban woodland was estimated. In this case, it was assumed that there is a close relationship between storage and carbon fixation in urban trees (ZHAO, 2010).

Estimation of GHG emissions from urban households in Ibagué and its possible mitigation

Information of emissions was obtained from Sierra estimates (2020), which was based on the use of fossil fuels and electricity in the residential sector of the city of Ibagué. The total number of households in each socioeconomic stratum (ENERTOLIMA, 2018) was considered for estimating emissions in the city. The estimation of the number of trees needed to compensate emissions, as a mitigation measure, was carried out using carbon fixation rates of the 15 most sequestrating species of urban trees Ibagué.

\section{Statistical Analysis}

A descriptive analysis was performed, and the Pearson correlation coefficient between carbon storage and fixation was estimated for all species and for the most dominant species of the urban area. Subsequently, a non-parametric Kruskal-Wallis variance analysis was performed to estimate differences of GHG emissions in households between 
different socioeconomic strata. In addition, comparisons in emissions between pairs of strata were made with the Dwass-Steel-Critchlow-Fligner test. Jamovi software was used for statistical analyses.

\section{Results}

Carbon storage in aboveground biomass of urban trees varied between $10.6 \mathrm{~kg}$ and $10.2 \mathrm{~kg} \mathrm{Mg} \mathrm{C} /$ tree, with an average $402 \pm 9.5 \mathrm{~kg} \mathrm{C} /$ tree. The most outstanding species in carbon storage is Samanea saman (Jacq.) Benth (samán), with $4.8 \pm 0.9 \mathrm{Mg} \mathrm{C} /$ tree, doubling Ficus dendrocida Kunth (caucho - rubber tree) in storage, which stores $2.4 \pm$ $1.5 \mathrm{Mg} \mathrm{C} /$ tree (Figure 2a). The rest of the 13 most important species concerning carbon, have a storage between $1.1 \pm 0.3$ and $2.3 \pm 0.2 \mathrm{Mg} \mathrm{C} /$ tree, values exceeded between two and three times by S. saman (Figure 2a).

Rates of carbon fixation in the most dominant species of urban trees are between 0.15 and $394.2 \mathrm{~kg} \mathrm{C} /$ tree/year with an average of $23.6 \pm 0.4 \mathrm{~kg} \mathrm{C} /$ tree/year (Figure $2 \mathrm{~b}$ ). S. saman shows the highest fixation rate $(111.9 \pm 28.4 \mathrm{~kg} \mathrm{C} /$ tree/year $)$, followed by Ficus elastica (ex. Hornem) (caucho de la india - india rubber tree), and Enterolobium cyclocarpum (Jacq) (orejero), with $91.2 \pm 20.1$ and $88.4 \pm 342.0 \mathrm{~kg} \mathrm{C} /$ tree/year, respectively. Carbon fixation rates of all other species decrease between 5 and $8 \mathrm{~kg} \mathrm{C} /$ tree/year, from $83.5 \pm$ $28.3 \mathrm{~kg} \mathrm{C} /$ tree/year in Attalea butyracea (Mutis LF), W. Boer (corozo), to Roystonea regia (Kunth) o.f Cook (palma real - royal palm tree) with $41.3 \pm 2.8 \mathrm{~kg} \mathrm{C} /$ tree/year (Figure 2b).

Among the most representative species, according to tree statutes of the city of Ibague (MOLINA, 2008) due to their storage and carbon fixation rates, stand out: Erythrina fusca Lour. (cachimbo), with $1.5 \pm 0.1 \mathrm{Mg} \mathrm{C} /$ tree $-63.5 \pm 4.2 \mathrm{~kg} \mathrm{C} /$ tree/year, Erythrina poeppigiana (Walp) O.F. Cook (cambulo) with $1.8 \pm 0.3 \mathrm{Mg} \mathrm{C} /$ tree $-76.3 \pm 11.1 \mathrm{~kg} \mathrm{C} /$ tree/year, Anacardium excelsum (caracolí) with $2.2 \pm 0.3 \mathrm{Mg} \mathrm{C} /$ tree $-81.1 \pm 7.1 \mathrm{~kg} \mathrm{C} /$ tree/year, Ceiba pentandra (L.) Gaertner (ceiba) with $1.2 \pm 0.3 \mathrm{Mg} \mathrm{C} /$ tree $-69.7 \pm 17.0$ $\mathrm{kg} / \mathrm{tree} /$ year, and S. saman with $4.8 \pm 0.9 \mathrm{Mg} \mathrm{C} /$ tree $-111.9 \pm 28.4 \mathrm{~kg} \mathrm{C} /$ tree/year (Figure 2ab). Another native and abundant species in Ibagué is Tabebuia rosea (Bertold) D.C. (ocobo), which showed a fixation rate of $25.5 \pm 2.3 \mathrm{~kg} \mathrm{C} /$ tree/year (Figure 2). Within the introduced species, stand Cedrela odorata (cedro amargo) native from Asia with 1.1 $\pm 0.3 \mathrm{Mg} \mathrm{C} /$ tree $-47.7 \pm 15.6 \mathrm{~kg}$ C/tree/year; Eucalyptus camaldulensis Dehn (eucalipto - eucalyptus) from Australia with $1.1 \pm 0.2 \mathrm{Mg} \mathrm{C} /$ tree $-42.9 \pm 9 \mathrm{~kg} \mathrm{C} /$ tree/year; Ficus benjamina $\mathrm{L}$. (caucho benjamín) with $1.5 \pm 0.2 \mathrm{Mg} \mathrm{C} /$ tree $-56.5 \pm 5.0 \mathrm{~kg} \mathrm{C} /$ tree/year; and F. elastica (caucho - rubber tree) from India with $2.0 \pm 0.8 \mathrm{Mg} \mathrm{C} /$ tree $-91.2 \pm 20.1$ $\mathrm{kg} \mathrm{C} /$ tree/year (Figure 2). 
Figure 2- Carbon storage and fixation rates of the most dominant perennial woody species of urban trees in Ibague, Colombia, 2019 - 2020
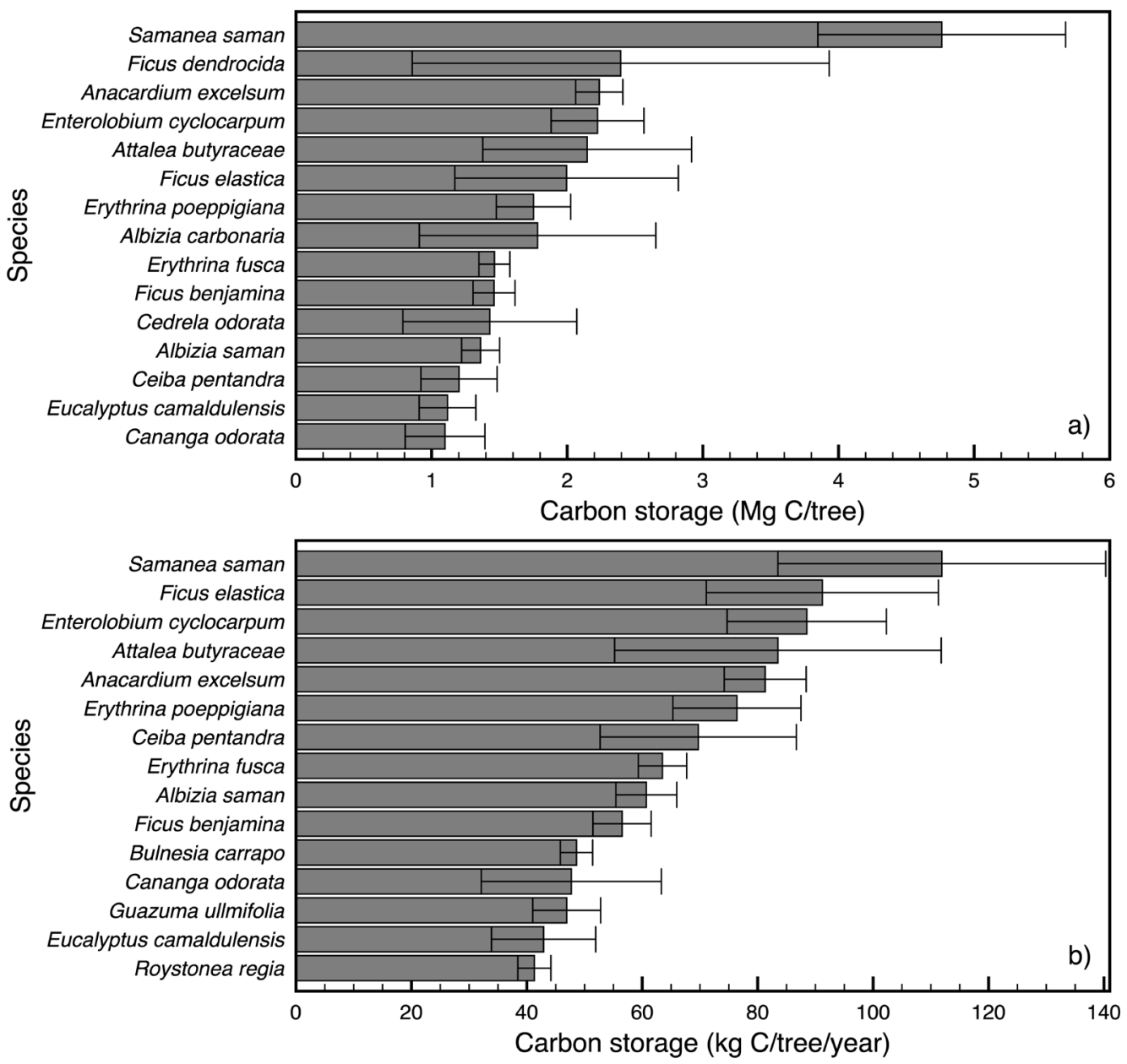

Values correspond to the average, and error bars represent the standard error of the mean.

Source: Authors.

An acceptable correlation between carbon storage and fixation in aboveground biomass of all species was found $(\mathrm{r}=0.74 ; \mathrm{p}<0.01)$ (Figure 3$)$. For S. saman, and E. cyclocarpum, Pearson correlation coefficient between storage and carbon fixation was even greater than in the rest of the main species analyzed $(\mathrm{r}=0.92 \mathrm{r}=0.85$, respectively). These stadigraphs confirm that models that estimate carbon fixation based on their storage, which in turn depends on their dap, may be developed. In contrast, in the other species, the correlation was not as acceptable $(0.55<\mathrm{r}<0.63)$ (Figure 3$)$. 
Figure 3 - Pearson correlation coefficient ( $r$ ) between carbon storage and fixation rates in aboveground biomass of the most dominant peren-

nial woody species of urban trees in Ibagué, Colombia, 2019 - 2020.
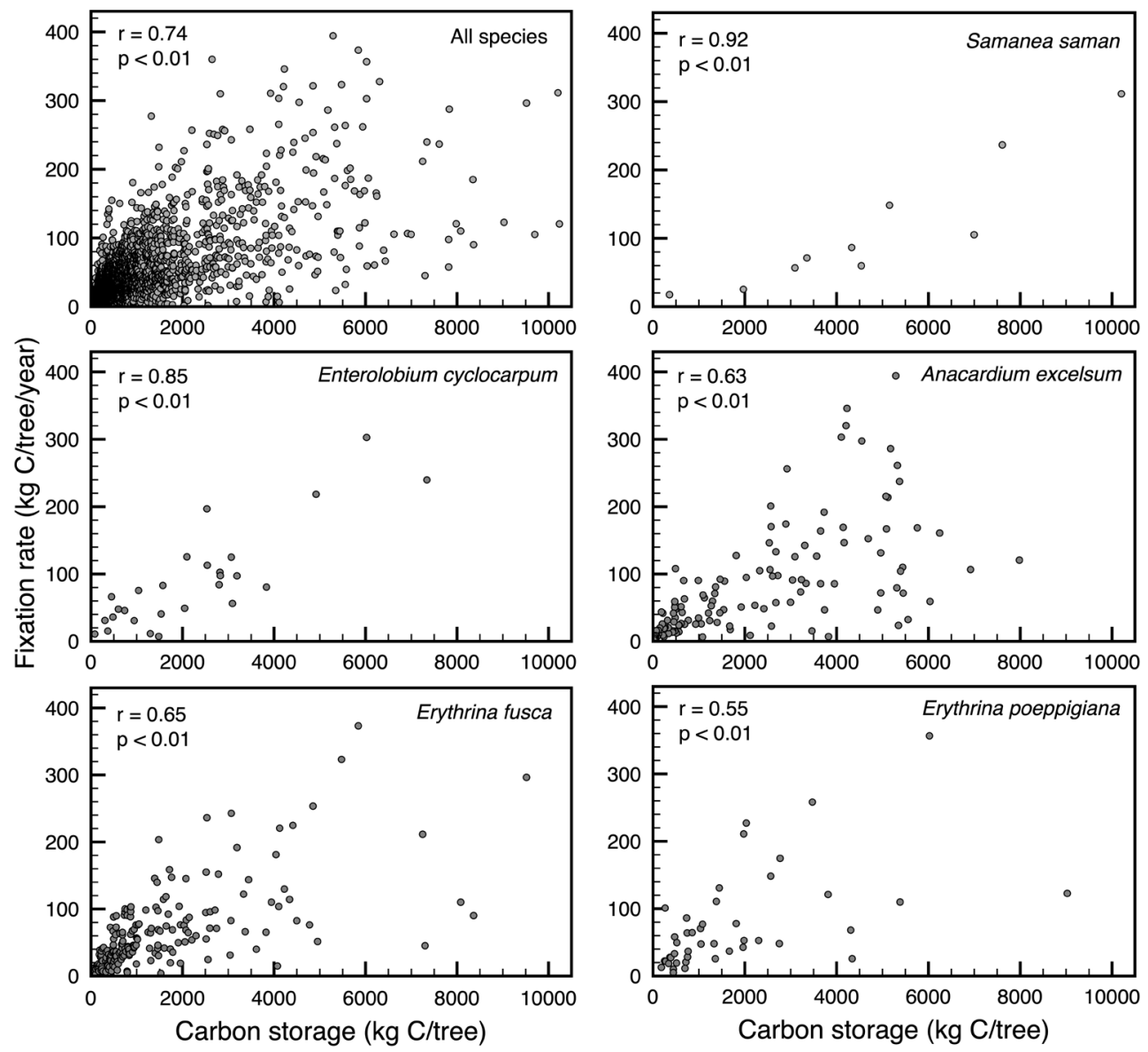

p: probability. Source: Authors.

GHG Emissions from households in Ibagué

Statistical differences $(\mathrm{p}<0,05)$ were detected in emissions per household in the city of Ibague among socioeconomic strata, which vary between $912.0 \pm 40.0$, and 1,189 $\pm 112 \mathrm{~kg} \mathrm{CO}_{2} /$ home. Stratum 2 had lower emissions, which were statistically different ( $\mathrm{p}$ $<0.01$ ) only with the strata 3 and 4; the other comparisons of strata pairs were statistically similar ( $p>0.05$ ) (Figure 4). A total emission of $169 \mathrm{Gg} \mathrm{CO}_{2} /$ year in the homes of the city was estimated, finding differences between strata, where the greatest emissions are recorded in stratum 2 with $69 \mathrm{Gg} \mathrm{CO}$ /year, while stratum 6 contributes only with $0.6 \mathrm{Gg} \mathrm{CO}_{2} /$ year. Stratum 1 contributed with $18.8 \%$ of total emissions, unlike stratum 
2 , with $41 \%$, and falling to stratum 3 , which accounted for $26 \%$, followed by strata 4,5 , and 6 with 11.9, 2.0 and 0.3\%, respectively (Figure 4).

Figure 4- $\mathrm{CO}_{2}$ Emissions of urban households in Ibagué, Colombia, 2018

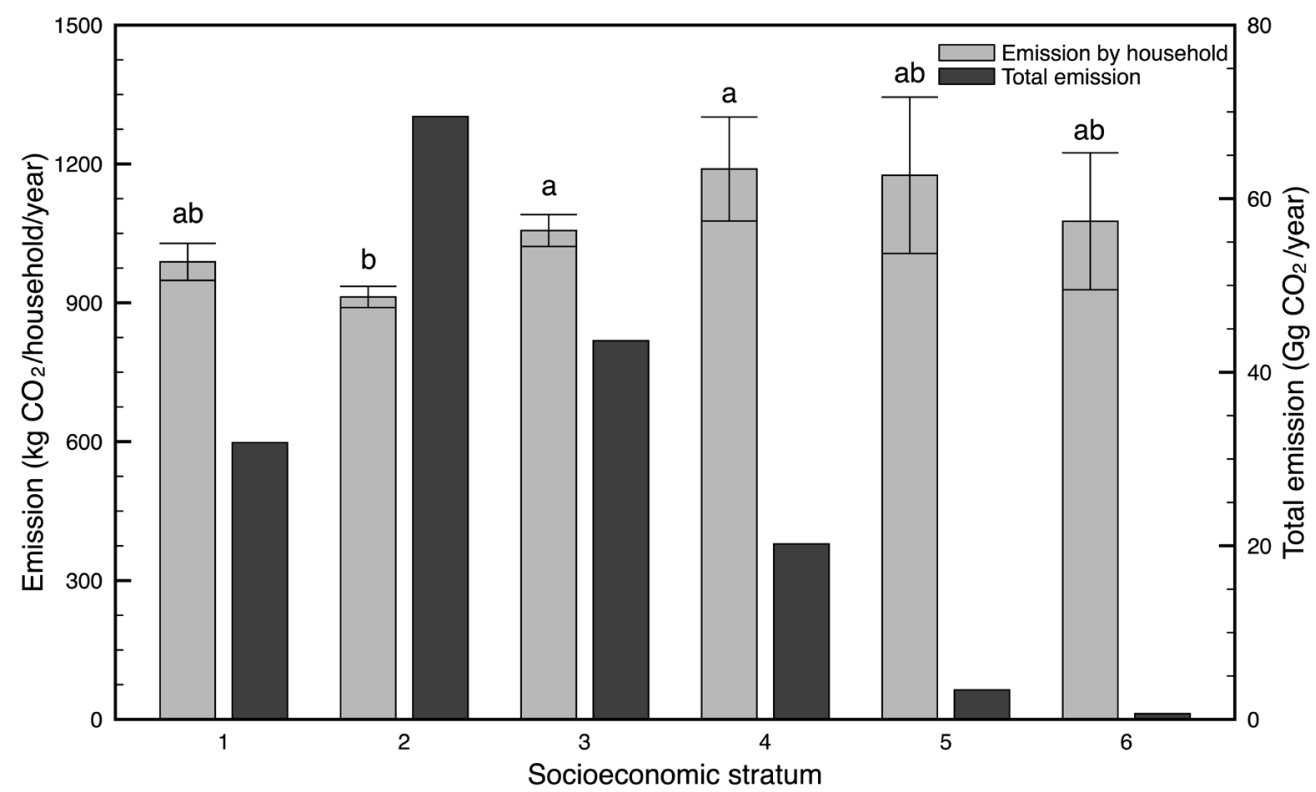

Values correspond to the average, and error bars represent the standard error of the mean. Different letters indicate statistical differences $(\mathrm{p}<0.05)$.

Source: Authors.

GHG Mitigation of emissions by urban trees

A carbon fixation rate of $1.04 \mathrm{Gg} \mathrm{C} /$ year was estimated in aboveground biomass for all urban trees in Ibagué, which means $3.81 \mathrm{Gg} \mathrm{CO}_{2} /$ year, showing that these green areas can capture and mitigate only $2.3 \%$ of total emissions from households in the city. The complete compensation of emissions from Ibagué households requires 412,000 S. saman trees, considering that this species has an average foxation rate of $411 \mathrm{~kg} \mathrm{CO} / \mathrm{tree} /$ year, unlike Roystonea regia, which has a carbon fixation rate of $152 \mathrm{~kg} \mathrm{CO}_{2} /$ tree/year that requires 1.1 million trees to compensate these emissions (Figure 5). For T. rosea, the tree badge of Ibagué, about 1.8 million trees would be required to mitigate these emissions. 
Figure 5. Number of trees of the most dominant species of urban trees needed to mitigate emissions per household in the city of Ibagué, Colombia, 2018-2020

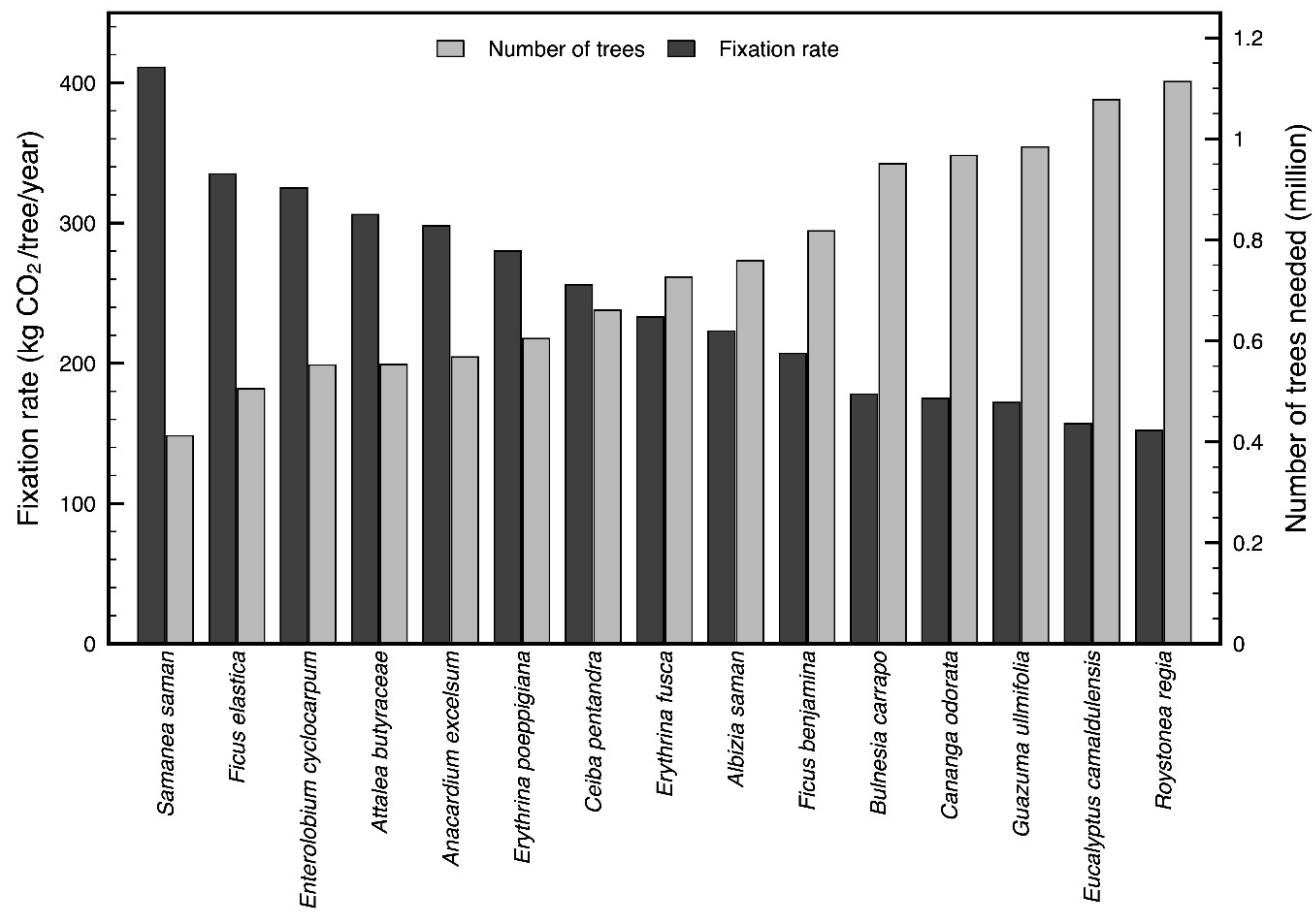

Species

Source: Authors.

\section{Discussion}

Heterogeneity of species and the specific characteristics from each one of them show their $\mathrm{CO}_{2}$ absorption capacity, especially S. saman, a determining species to mitigate GHG by urban trees of Ibagué by having the biggest carbon storage and sequestration values. It should be noted that carbon sequestration is takes place mostly during the development of the trees. Then, as years pass, when trees have reached their full maturity, they capture only small amounts of $\mathrm{CO}_{2}$ required for soil respiration and theirs. Thus, it is not important how much carbon they capture immediately, but how much carbon they capture and fix throughout their lives (AGUDELO, 2009).

In this current study, E. fusca highlighted by storing $1.5 \mathrm{Mg} \mathrm{C} /$ tree, which contrasts with findings of Rodriguez (2018), who estimated $8.0 \mathrm{Mg} \mathrm{C} /$ tree in Envigado and Medellin, Colombia. Although the results are dissimilar, possibly due to age differences of the trees, the potential climate change mitigation of this species in urban forests of the country is evinced. Another outstanding species in carbon storage and fixation was F. benjamina with $1.5 \mathrm{Mg} \mathrm{C} /$ tree and $56.5 \mathrm{~kg} \mathrm{C} /$ tree/year, respectively. Similar results were 
found in the study by Cortes and Matias (2018) in Parque Los Fundadores in the city of Villavicencio-Colombia, estimating a $0.48 \mathrm{Mg}$ C/tree storage.

Although some species such as A. excelsum and F. elastica have great benefits in climate change mitigation, it is important to consider that they generate high risks in public spaces, because of infrastructure damage (MOLINA, 2008; CORTES; MATIAS, 2018). In contrast, Molina (2008) recommended species such as E. fusca, C. pentandra, S. saman, and S. poeppigeana for strengthening the ecological structure of Ibagué, which showed important benefits on their carbon sequestration and climate change mitigation. In Villavicencio (Colombia), Prieto and Garzon (2007) agreed to recommend species such as E. poeppigeana and C. pentandra for strengthening the main ecological structure, because they are optimal for soil conservation, erosion control, and recovery of degraded lands because they have a high capacity to fix nitrogen to the soil. These benefits make cities economically and environmentally sustainable (FAO, 2016).

In the selection of the most beneficial tree species for urban trees must be considered, in addition to carbon fixation, the offer of other ES such as shade supply, beautification of the city and air pollution mitigation. Native species produce food for fauna, especially birds and small mammals such as bats and squirrels, and a wide variety of insects, so native species not only comply with ornamental and environmental aspects, but also with ecological (PRIETO; GARZÓN, 2007).

GHG emission estimates from households in Ibagué showed that there was no effect of the socioeconomic status. This may be due to two factors in the upper strata: first, to the increased use of equipment, but probably more energy-efficient, such as efficient appliances, high-end cars and energy-saving bulbs (SCOTUS; SÁNCHEZ; PÉREZ, 2016); and second, the members of these households consume more foods that do not require cooking or are prepared outside the home (BELALCAZAR; TOBAR, 2013; GROVE, VILLA, 2016).

Balance between household emissions and $\mathrm{CO}_{2}$ fixation rate allows suggesting that urban trees can mitigate only a small proportion of GHG emissions. In this balance, it is necessary to look for additional alternatives, as mentioned by the World Health Organization, which states that cities must meet a minimum surface of green areas between 0.5 and $1.0 \mathrm{ha} /$ inhabitant with a distance lower or equal to $300 \mathrm{~m}$ away from their residence, as described in UN-HABITAT (2018), and non-compliance with this rule in the city is evident in this research.

Assuming that Ibagué acquires the recommended area per inhabitant, carbon sequestration by urban trees could significantly increase. The small extension of green areas in urban zones of the city is possibly because these are concentrated in the highest strata; whereas in many streets and avenues of the city center and in the lower strata, there is a deficit of urban trees, caused by rapid population growth and poor planning of green areas (MOLINA, 2008).

Lindén et al. (2010) estimated storage in parks built in Helsinki (Finland) at 25 $\mathrm{Mg} \mathrm{C} /$ ha, important information for planning urban green areas. Mohamed et al. (2018) conducted extensive research of vertical vegetation systems in tropical climate, beyond 
urban forests, and showing the benefits of adapting the natural environment into the urban, built in an eco-friendly way, considering its carbon sequestration potential and climate change mitigation. Reynolds et al. (2017) estimated the total storage of the public urban public woodland in the metropolitan area of the Aburrá Valley (Colombia) at $103820 \mathrm{Mg} \mathrm{CO}_{2}$, with a net sequestration of 2.9-5.3 $\mathrm{Gg} \mathrm{CO}_{2}$ /year, a value comparable to the $3.81 \mathrm{Gg} \mathrm{CO}_{2}$ /year estimated in the current study. Differences can be caused by the zone of the study area, involving differences in the number of trees, additionally, Reynolds et. al (2017) also included biomass belowground.

Trees in urban areas have other benefits in the fight against climate change, such as preventing $\mathrm{CO}_{2}$ emissions indirectly through energy saving in buildings for heating and cooling (NOWAK, CRANE, 2002). Therefore, in this research, it is likely that the contribution of urban trees to mitigate climate change is underestimated, but it solves several questions, including the notorious carbon storage and fixation rates difference among species. The estimation of the number of trees needed to mitigate $\mathrm{CO}_{2}$ emissions from households in the city of Ibagué would help in the plans of Ibagué green city strategy, and it is a tool for future infrastructure decisions, since there are few planning strategies for land use, highly affecting the green areas of cities (FAO, 2016).

A proposal for mitigation of emissions from households in the city, is the extension of public urban trees as public policy. Depending on the tree species to be used, from 412,000 to 1.1 million trees may be required. The strategies to neutralize emissions must be a priority, as the city had more than 199,357 vehicles and motorcycles in 2019, which are determining in the air quality (ALCALDÍA MUNICIPAL DE IBAGUÉ, 2019). Also, the fact that the unplanned urban growth in the last 16 years has resulted in a total loss of 244.5 ha and the disappearance of 58 forest units in the urban area of Ibagué is highly relevant (DIAZ, 2019). This problem was also evident in the global urban tree cover, where a reduction of 26.7 to $26.5 \%$ between 2012 and 2017 was recorded (NOWAK; REENFIELD, 2020). The prevailing idea claims that the progress made by climate science is a solid foundation for the development of public policies, reinforce or implement new governance strategies, with goals aimed at local scenarios, based on scientific foundations. Additionally, all political sectors must work together without keeping any interest in any sector (LEZAMA, 2014).

The use of clean technologies should be promoted and adopted, considering the use of solar panels for public lighting and solar water heaters, stimulating consumption of energy-efficient technology (GUTMAN, 2007; BARTON, 2009; ANDRADE et al, 2013; SANCHEZ, REYES, 2015). Also, energy saving must be encouraged, replacing refrigeration equipment that is over 10 years old, disconnecting devices without immediate use, avoiding the standby mode in appliances, reducing the use of air conditioning and other devices with high energy consumption (LACKNER, 2012; MINMINAS, 2016). It is important to develop strategies of smart mobility to reduce GHG emissions in the city and improve the air quality (ZAMUDIO, 2016), share vehicles in urban and rural areas, use greener transportation forms and, as a vision for the future, change the public transport system with a more efficient and sustainable one, with fewer emissions, especially 
in intermediate cities like Ibagué (UDDIN, 2012).

The implementation of carbon market, where the forestry sector and change of land use are important in voluntary carbon market projects is added, because of the materialization of new demand sources, and the volume of compensations generated. Between 2016 and 2018, commercialization of these activities increased from $13.9 \mathrm{Mt} \mathrm{CO}_{2}$ e to $50.7 \mathrm{MtCO}_{2} \mathrm{e}$, as the world requires credible and available climate solutions that can be executed in the present (DONOFRIO; MAGUIRE; MERRY; ZWICK, 2019). The average price of carbon during 2018 in the world ranged between $\mathrm{U} \$ 3$ and $\mathrm{U} \$ 6 / \mathrm{Mg} \mathrm{CO}_{2} \mathrm{e}$, with an average of $\mathrm{U} \$ 2.6 / \mathrm{Mg} \mathrm{CO}_{2} \mathrm{e}$ for Latin America and the Caribbean (HAMRICK; GALLANT, 2018). This voluntary or strict compliance strategy adopted by countries that buy or sell carbon bonds has allowed a higher appropriation of individual, business, and government environmental care. A small sample of this is that, for 2019, Colombia has assigned a value of $16,422 \mathrm{COP} / \mathrm{Mg} \mathrm{CO}_{2} \mathrm{e}\left(\mathrm{U} \$ 5 / \mathrm{Mg} \mathrm{CO}_{2} \mathrm{e}^{1}\right)(\mathrm{SFC}, 2020)$, as a domestic tax to gasoline and diesel (DIAN, 2019).

\section{Conclusions}

The research estimated that there is variation in carbon storage fixation among the most dominant perennial woody species of urban trees in Ibagué. Correlation between carbon fixation and storage in these species could allow, in more detailed studies, the development of models that estimate fixation based on storage, which is an important tool for monitoring this ecosystem service in cities.

Urban woodland fixes around $3.81 \mathrm{Gg} \mathrm{CO}_{2} /$ year, which represents only $2.3 \%$ of emissions in the city. Mitigation of $169.2 \mathrm{Gg} \mathrm{CO}_{2}$ /year from households would be achieved by having between 412,000 and 1.2 million trees of the most dominant species in the city of Ibague. This indicates the need to increase urban tree plantations, in addition to enhance the diversity of native species properly established and managed to avoid phytosanitary problems or damage to the structure of public services or asphalts of road networks. There should also be work on replacing the use of electricity and fossil fuels with alternative energy sources. These mitigation strategies would support the plans of Ibagué, as a green city strategy.

\section{Recommendations}

Carbon storage estimates in urban trees may have errors due to the use of general biomass models, which do not consider the characteristics of handling this type of trees, such as continuous pruning. The development and validation of general models for specific application under these conditions is recommended.

Studies about the impact of urban trees in microclimatic conditions would be an ideal component for a wider vision of their benefits concerning climate change and climate variability. Green city policies, like those of Ibagué, require more detailed studies such as this current, a reason why funding research and development of goods practice should be a 
key element. Likewise, environmental education programs for the population and support to reduce energy consumption and the resulting greenhouse gas emissions are required.

\footnotetext{
${ }^{1}$ Value estimated by taking the average TRM for Colombia during 2019 (3282.39 COP/USD).
}

\section{Acknowledgments}

We thank the Central Research Office (Oficina Central de Investigaciones) of Universidad del Tolima for financing project 260130517, and CORTOLIMA for providing the database of the Urban Tree Census in the city of Ibague, in which Corporación San Jorge, Cemex, Concesión San Rafael, Mayoralty of Ibagué (Alcaldía de Ibagué) and Universidad del Tolima also participated.

\section{References}

AGUDELO, M. Biomasa aérea y contenido de carbono en bosques de Quercus humboldtii y Colombobalanus excelsa: corredor de conservación de robles Guantiva - La Rusia - Iguaque (Santander - Boyaca). (Tesis de pregrado) - Facultad de Ciencias Básicas, Universidad Autónoma de Occidente, Santiago de Cali. 2009.

ALCALDÍA MUNICIPAL DE IBAGUÉ. 2016. Plan de Desarrollo 2016-2019. Disponible en $<$ https://www.ibague.gov.co/portal/seccion/contenido/index.php?type $=2 \& c n t=5>$. Acceso en 9. Jun. 2020.

ALCALDÍA MUNICIPAL DE IBAGUÉ. 2019. Parque automotor de Ibagué supera los 199.300 vehículos y motocicletas. Disponible en $<$ https://www.ibague.gov.co/portal/seccion/ noticias/index.php?idnt $=6755>$. Acceso en 9. Jun. 2020.

ALCALDÍA MUNICIPAL DE IBAGUÉ. 2020. Plan de Desarrollo 2020-2023. Disponible en $<$ https:/www.ibague.gov.co/portal/seccion/contenido/contenido.php?type $=3 \& \mathrm{cnt}=86 \&$ subtyp $\mathrm{e}=1 \&$ subcnt $=418>$. Acceso en 9. Jun. 2020.

ÁLVAREZ, E.; SALDARRIAGA, J.; DUQUE, A.; CABRERA, K.; YEPES, A., NAVARRETE, D.; PHILLIPS, J. Selección y validación de modelos para la estimación de la biomasa aérea en los bosques naturales de Colombia. Bogotá D.C., Colombia. 2011.

ANDRADE, H.; SEGURA, M.; CANAL, D.; GÓMEZ, M.; MARÍN, M.; SIERRA, E.; GUEPENDO, I.; ALVARADO, J.; FERIA, M. Estrategias de adaptación al cambio climático en sistemas de producción agrícola y forestal en el departamento del Tolima. Ibagué- Tolima, Colombia, Sello Editorial Universidad del Tolima, 2013.

ARBOLEDA, L.; VILLA, P. Preferencias alimentarias en los hogares de la ciudad de Medellín, Colombia. Saúde Soc. São Paulo, v. 25, n. 3, 750-759. 2016. 
BARÓ, F.; CHAPARRO, L.; GÓMEZ-BAGGETHUN, E.; LANGEMEYER, J.; NOWAK, D.; TERRADAS, J.; Contribution of Ecosystem Services to Air Quality and Climate Change Mitigation Policies: The Case of Urban Forests in Barcelona, Spain. AMBIO, n. 43, 466- 479. 2014. doi: 10.1007/s13280-014-0507-x

BARTON, J. Adaptación al cambio climático en la planificación de ciudades regiones. Revista de Geografía Norte Grande, v 43: 5-30. 2009.

BELALCAZAR, D.; TOBAR, L. Determinantes sociales de la alimentación en familias de estratos 4, 5 y 6 de la localidad de Chapinero de Bogotá D.C. Rev. Fac. Nac. Salud Pública. v. 31, n. 1, 40-47. 2013.

BORRERO, J. Biomasa aérea y contenido de carbono en el campus de la pontificia universidad javeriana de Bogotá. (Tesis de pregrado) - Facultad de Estudios Ambientales y Rurales, Pontificia Universidad Javeriana, Bogotá. 2012.

CHAROEKIT, S.; YIEMWATTANA, S. Living walls and their contribution to improved thermal comfort and carbon emission reduction: A review. Building and Environment, v.105, Pages 82-94. 2016. doi:10.1016/j.buildenv.2016.05.031

CHAVE, J.; ANDALO, C.; BROWN, S.; CAIRNS, M.; CHAMBERS, J.; EAMUS, D.; FOLTER, H.; FROMARD, F.; HIGUCHI, N.; KIRA, T.; LESCURE, J.; NELSON, B.; OGAWA, H.; PUIG, H.; RIERA, B.; YAMAKURA, T. Tree allometry and improved estimation of carbon stocks and balance in tropical forests. Oecología, v. 145, 87-99. 2005. doi: 10.1007/s00442-005-0100-x

CORPORACIÓN AUTÓNOMA REGIONAL DEL TOLIMA (CORTOLIMA). 2020. Ubicación geografía de Ibagué. Disponible en < https://www.cortolima.gov.co/search/node/Ubicacion\%20geografica\%20de\%20ibague >. Acceso en 9. Jun. 2020.

CORTOLIMA., CORPORACIÓN SAN JORGE., CEMEX., CONCESIÓN SAN RAFAEL., ALCALDÍA DE IBAGUÉ., UNIVERSIDAD DEL TOLIMA. Censo del arbolado urbano realizado 2013 a 2016. Radicado: 0336 del 10 de junio de 2020. CORTOLIMA, Ibagué: 2020.

CORTES, J.; MATIAS, E. Estimación de la capacidad potencial de fijación de $\mathrm{CO}_{2}$ y producción de $\mathrm{O}_{2}$, como servicio ecosistémico suministrado por el arbolado del parque los fundadores y la alameda de la avenida 40 en el municipio de Villavicencio (Meta). (Tesis de pregrado)Facultad de Ingeniería Ambiental, Universidad Santo Tomás, Villavicencio. 2019.

DEPARTAMENTO ADMINISTRATIVO NACIONAL DE ESTADÍSTICA - DANE. Proyección de la población. Bogotá: 2018. DÍAZ, M. Sostenibilidad ambiental de los bosques urbanos en la ciudad de Ibagué, 2000-2018. (Trabajo de Posgrado) - Universidad Pedagógica y Tecnológica de Colombia, Tunja. 2019.

DIRECCIÓN DE IMPUESTOS Y ADUANAS NACIONALES DE COLOMBIA (DIAN). Resolución n. 000009 30/01 de 2019. Por la cual se ajustan las tarifas del impuesto nacional a la gasolina y al ACPM, y del impuesto nacional al carbono. Disponible en: < https://www.dian.gov. co/normatividad/Normatividad/Resoluci\%C3\%B3n\%20000009\%20de\%2028-01-2019.pdf >. Acceso en 9. Jun. 2020. 
DONOFRIO, S.; PATRICK, M.; MERRY, W.; STEVE, Z. Financing Emissions Reductions forthe Future State of the Voluntary Carbon Markets 2019. Available on: < https://www.forest-trends.org/wpcontent/uploads/2018/09/VCM-Q1-Report_Full-Version-2.pdf > Access in: 10. Jun. 2020.

ENERTOLIMA. Respuesta de derecho de petición con radicado: 201800026472. Compañía Energética del Tolima S.A. E.S.P. Ibagué: 2018.

ESCOTO, A.; SÁNCHEZ, L.; PÉREZ G. Hogares y energía eléctrica en México. Revista Espinhaço, v. 5, n. 2, 30-43. 2016.

FINANCIERA DEL DESARROLLO - FINDETER. Ibagué sostenible 2037 Territorio conector, colectivo y competitivo. Ibagué: 2018.

FOOD AND AGRICULTURA ORGANIZATION OF THE UNIDE NATIONS (FAO). 2016. Building greener cities: nine benefits of urban tres. Available on <http:/www.fao.org/zhc/ detail-events/en/c/454543/. >. Access in: 8. Jun. 2020.

GRIMM, N.; FAETH, S.; GOLUBIEWSKI, N.; REDMAN, C.; WU, J.; BAI, X.; BRIGGS, J. GLOBAL. Change and the Ecology of Cities. Science, v. 319, n. 5864, 756-760, 2008. doi:10.1126/ science. 1150195

GUTMAN, V. Cambio climático e incentivos a la innovación en tecnologías limpias: ¿puede más mercado corregir la mayor falla de mercado de la historia?. (Tesis de posgrado)- Facultad de Ciencias Económicas, Universidad de Buenos Aires, Buenos Aires Argentina. 2007

HAMRICK, K.; GALLANT, M. Voluntary carbon markets outlooks and First- Quarter Trends, 2018. Available on: < https://www.forest-trends.org/wpcontent/uploads/2018/09/VCM-Q1-Report_Full-Version-2.pdf > Access in: 10. Jun. 2020.

INSTITUTO DE HIDROLOGÍA, METEOROLOGÍA Y ESTUDIOS AMBIENTALES (IDEAM). c2020. Visor de Datos Instantaneos del IDEAM. Disponible en < "http://visormapas. ideam.gov.co/datainmotiongeox/productos/generales/estaciones/automaticas/crudos/instantaneos/">. Acceso en 9. Jun. 2020.

INSTITUTO DE HIDROLOGÍA, METEOROLOGÍA Y ESTUDIOS AMBIENTALES -IDEAM. Inventario nacional y departamental de gases de efecto invernadero - Colombia. Bogotá: 2012.

JUÁREZ, Y. Dasometría apuntes de clase y guía de actividades prácticas. 1. ed. Cochabamba, Bolivia. 2014.

LACKNER, M. Energy Efficiency: Comparison of Different Systems and Technologies. In IN WEI-YIN CHEN, SEINER, J. SUZUKI, T. and LACKNER M. (Eds.), Handbook of Climate Change Mitigation. 2012, pp. 841- 907. doi:10.1007/978-1-4419-7991-9

LEZAMA, J. La política Internacional del cambio climático. Sociedad y ambiente, v. 1, n. 3, 104-117. 2014. 
LINDÉN, L.; RIIKONEN, A.; SETÄLÄ, H.; YLI-PELKONEN, V. Quantifying carbón stocks in urban parks under cold climate conditions. Urban Forestry $\&$ Urban Greening, v.49, 2020. doi. org/10.1016/j.ufug.2020.126633

LOPEZ, S.F.; MARTÍNEZ, T.; BENAVIDES, HM.; GARCÍA, M.; ÁNGELES, G. Reservorios de biomasa y carbono en el arbolado de la primera sección del Bosque de Chapultepec, Ciudad de México. Madera y Bosques, v. 24, n. 3, e2431620, 2018. doi.org/10.21829/myb.2018.2431620.

MCHALE, M.; MCPHERSON, E.; BURKE, I. The potential of urban tree plantings to be cost effective in carbon credit markets. Urban Forestry $\&$ Urban Greening, v. 6, n.1, 49-60. 2007. doi:10.1016/j.ufug.2007.01.001

MINISTERIO DE MINAS Y ENERGÍA- MinMinas. Plan de acción indicativo de eficiencia energética 2017 - 2022 una realidad y oportunidad para Colombia. Bogotá: 2016.

MOHAMED, S.; PERISAMY E.; HUSSEIN, H.; MYEDA N.; ZAINON N. Vertical Greenery System in Urban Tropical Climate and its Carbon Sequestration Potential: A Review. Ecological Indicators, v. 91, 57-70. 2018. doi: 10.1016/j.ecolind.2018.03.086

MOLINA, L. Árboles para Ibagué. Especies que fortalecen la Estructura Ecológica Principal. Grupo de investigación Ciudad, Medio Ambiente y Hábitat Popular. Nodo: Arquitectura. Ciudad. Medio Ambiente, v.3, n.5, 71-84. 2008.

NATIONAL OCEANIC \& ATMOSPHERIC ADMINISTRATION (NOAA). c2020. Concentración de $\mathrm{CO}_{2}$ en la atmósfera entre enero de 1966 y enero de 2019. Earth System Research Laboratory at Manua Loa. U.S. Disponible en < http://www.esrl.noaa.gov/gmd/ccgg/trends/data. html>. Acceso en 9. Jun. 2020.

NOWAK D.J.; CRANE D.E. Carbon storage and sequestration by urban trees in the USA. Environmental Pollution, v. 116, n. 3, 381-389. 2002. doi: 10.1016/S0269-7491(01)00214-7

NOWAK, D.; GREENFIELD, E. The Increase of Impervious Cover and Decrease of Tree Cover within Urban Areas Globally (2012-2017). Urban Forestry and Urban Greening, v. 49. 2020. doi: 10.1016/j.ufug.2020.126638

PANEL INTERGUBERNAMENTAL DEL CAMBIO CLIMÁTICO - IPCC. Gases de Efecto Invernadero, IPCC Fourth Assessment Report: Climate Change 2007. Informe del Grupo de Trabajo I - Base de las Ciencias Físicas. Ginebra, Suiza: 2007.

PANEL INTERGUBERNAMENTAL DEL CAMBIO CLIMÁTICO - IPCC. Cambio Climático 2014 mitigación del cambio climático resumen para responsables de políticas y resumen técnico. Cambridge, Reino Unido y Nueva York, NY, Estados Unidos de América: 2014.

PRIETO, L.; GARZÓN, B. Árboles para Villavicencio especies que fortalecen la Estructura Ecológica Principal. Revista nodo, v. 2, n. 3, 85-98. 2007.

REYNOLDS, C.C.; ESCOBEDO, F.J.; CLERICI, N.; ZEA-CAMAÑO, J. Does "Greening” of Neotropical Cities Considerably Mitigate Carbon Dioxide Emissions? The Case of Medellin, Co- 
lombia. Sustainability, v. 9, n. 785, 1-16. 2017.

RODRÍGUEZ, A. Estimación del crecimiento, la biomasa y la captura de carbono de tres especies arbóreas del bosque urbano en los municipios de Medellín y Envigado. (Tesis de pregrado), Universidad EIA, Envigado. 2018.

RUANO, J. Estimación de la captura de carbono en el Ecoparque de las garzas, Cali Valle del Cauca. (Tesis de pregrado) - Facultad de Ciencias Básicas, Universidad Autónoma de Occidente, Santiago de Cali. 2019.

SALBITANO, F; BORELLI, S.; CONIGLIARO, M.; CHEN, Y. Directrices para la silvicultura urbana y periurbana. Organización de las Naciones Unidas para la Alimentación y la Agricultura, Directrices para la silvicultura urbana y periurbana, Montes n 178, Roma, 2017.

SÁNCHEZ, L.; REYES, O. Medidas de adaptación y mitigación frente al cambio climático en América Latina y el Caribe. Una revisión genera. Santiago, Chile. 2015. Disponible en: $<$ https://repositorio.cepal.org/bitstream/handle/11362/39781/S1501265_es.pdf > . Acceso en 11 jun. 2020

SIERRA, E. (2020). Relación entre la emisión de gases de efecto invernadero y las características sociodemográficas y socioeconómicas de hogares del municipio de Ibagué, Tolima, Colombia. (Tesis de Maestría)-Facultad de Ingeniería Forestal, Universidad del Tolima, Tolima, Colombia. 2020.

SUPERINTENDENCIA FINANCIERA DE COLOMBIA. c2020. Histórico TRM para estados financieros. Disponible en <https://www.superfinanciera.gov.co/jsp/9332>. Acceso en 9. Jun. 2020.

TIMILSINA, N.; ESCOBEDO, F.; STRAUDHAMMER, C.; BRANDEIS, T. Analyzing the causal factors of carbon stores in a subtropical urban forest. Ecological Complexity, v.20, 23-32. 2014. doi: 10.1016/j.ecocom.2014.07.001

UDDIN, W. Mobile and Area Sources of Greenhouse Gases and Abatement Strategies. In Wei-Yin Chen, Seiner, J. Suzuki, T. and Lackner M. (Eds.), Handbook of Climate Change Mitigation. 2012, pp.775-839. doi:10.1007/978-1-4419-7991-9

UNITED NATIONS. Revision of World Urbanization Prospects: the 2018 revision. New York: 2018.

UNITED NATIONS HUMAN SETTLEMENTS PROGRAMME - UN-HABITAT. Developing public space and land values in cities and neighbourhoods. Disponible en: https://unhabitat.org/developing-public-space-and-land-values-in-cities-and-neighbourhoods. Acceso en 11 jun. 2020

VILLANUEVA, R.; LEÓN, F; OSORIO, C.; SÁNCHEZ, D. Renovación y ampliación de la terminal aeroportuaria perales Ibague -Tolima. (Tesis de pregrado)- Facultad de Arquitectura y Artes, Universidad Piloto de Colombia, Bogotá. 2016. 
ZAMUDIO, J. Estrategias para mitigar la contaminación del aire en zonas aledañas a grandes avenidas de Bogotá. (Tesis de posgrado). Universidad Nacional de Colombia. Bogotá, Colombia. 2016.

ZHAO, M.; ZHENG-HONG K.; ESCOBEDO, F.; GAOA, J. Impacts of urban forests on offsetting carbon emissions from industrial energy use in Hangzhou, China. Journal of Environmental Management, v. 91, 807-813. 2010. doi: 10.1016/j.jenvman.2009.10.010 
Luis Miguel Acuña-Simbaqueva

$\checkmark 1 m a c u n a s @ u t . e d u . c o$

ORCiD: https://orcid.org/0000-0003-1733-2485
Submitted on: 05/11/2020

Accepted on: 17/03/2021

2021;24e:0191

\section{Hernán J. Andrade}

$\checkmark$ hjandrade@ut.edu.co

ORCiD: https://orcid.org/0000-0002-3398-294X

\section{Milena A. Segura}

$\checkmark$ masegura@ut.edu.co

ORCiD: https://orcid.org/0000-0002-4813-1224

\section{Erika Sierra-Ramírez}

$\checkmark$ esierrar@ut.edu.co

ORCiD: https://orcid.org/0000-0002-4449-2401

\section{Diana Skarly Canal-Daza}

$\checkmark$ dscanal@ut.edu.co

ORCiD: https://orcid.org/0000-0002-3775-6210

\section{Oscar Enrique Greñas-Corrales}

$\checkmark$ ogrenas@ut.edu.co

ORCiD: https://orcid.org/0000-0003-2229-5404

How to cite: ACUÑA, 1.M; ANDRADE, H.J; SEGURA, M.A; SIERRA, E; CANAL. D.S; GREÑAS, O.E. Mitigation of greenhouse gas emissions from households by urban woodland in Ibagué-Colombia. Ambiente $\&$ Sociedade. São Paulo, v. 24, p. 1-20, 2021. 


\title{
Mitigação de emissões de GEE de familias por árvores urbanas em Ibagué-Colômbia
}

\author{
Luis Miguel Acuña-Simbaqueva \\ Hernán J. Andrade \\ Milena A. Segura \\ Erika Sierra-Ramírez \\ Diana Skarly Canal-Daza
}

São Paulo. Vol. 24, 2021

Artigo Original
Resumo: As árvores são essenciais nas cidades para capturar $\mathrm{CO}^{2} \mathrm{e}$, por sua vez, contribuem para mitigar as mudanças climáticas. $\mathrm{O}$ armazenamento e fixação de carbono de biomassa acima do solo na floresta urbana de Ibagué foram estimados com um censo em 2013-2016 e uma re-medição de $15 \%$ dos indivíduos em 2019-2020. O número de árvores necessárias para as principais espécies foi estimado para mitigar as emissões domésticas de gases de efeito estufa. As árvores urbanas fixam cerca de 3,81 $\mathrm{Gg}$ de $\mathrm{CO}^{2} /$ ano, o que representa apenas 2,3\% das emissões da cidade. A mitigação de $169,2 \mathrm{Gg} \mathrm{CO}^{2}$ /ano das residências da cidade seria alcançada com entre 412 mil e 1,2 milhão de árvores das espécies mais dominantes. Os esforços baseados em infraestrutura verde para compensar as emissões urbanas no nível municipal devem ser coordenados com políticas territoriais em escalas amplas.

Palavras-chave: Armazenamento, fixação, política ambiental, serviços ecossistêmicos, silvicultura urbana.

Como citar: ACUÑA, 1.M; ANDRADE, H.J; SEGURA, M.A; SIERRA, E; CANAL. D.S; GREÑAS, O.E. Mitigação de emissões de GEE de famílias por árvores urbanas em Ibagué-Colômbia. Ambiente $\mathbb{\&}$ Sociedade. São Paulo, v. 24, p. 1-20, 2021. 


\title{
Mitigación de emisiones de gases de efecto invernadero
}

\author{
Luis Miguel Acuña-Simbaqueva \\ Hernán J. Andrade \\ Milena A. Segura \\ Erika Sierra-Ramírez \\ Diana Skarly Canal-Daza \\ Oscar Enrique Greñas-Corrales
}

São Paulo. Vol. 24, 2021

Artículo original
Resumen: Los árboles son indispensables en las urbes para capturar $\mathrm{CO} 2$, y a su vez, contribuir a mitigar el cambio climático. Se estimó el almacenamiento y fijación de carbono en biomasa arriba del suelo en el arbolado urbano de Ibagué con un censo del 2013-2016 y una remedición del 15\% de los individuos en el período 2019-2020. Se estimó el número de árboles requeridos de las principales especies para mitigar las emisiones de gases de efecto invernadero de los hogares. El arbolado urbano fija cerca de 3,81 Gg CO2/año, lo que representa solo el 2,3\% de las emisiones de la ciudad. La mitigación de 169,2 Gg CO2/año de los hogares de la ciudad se lograría teniendo entre 412 mil y 1,2 millones de árboles de las especies más dominantes. Los esfuerzos basados en infraestructura verde para compensar la emisión urbana a nivel municipal deben coordinarse con políticas territoriales a escalas amplias.

Palabras-clave: Almacenamiento, fijación, política ambiental, servicios ecosistémicos, silvicultura urbana.

Como citar: ACUÑA, 1.M; ANDRADE, H.J; SEGURA, M.A; SIERRA, E; CANAL. D.S; GREÑAS, O.E. Mitigación de emisiones de gases de efecto invernadero de hogares por arbolado urbano en Ibagué-Colômbia. Ambiente \& Sociedade. São Paulo, v. 24, p. 1-20, 2021.

DOI: http://dx.doi.org/10.1590/1809-4422asoc20200191vu2021L3AO 